\title{
Laying the Foundations of Physical Culture: The Stadium Revolution in Socialist Yugoslavia \\ Richard Mills
}

\begin{abstract}
After liberation, the incipient socialist Yugoslavia engaged its citizens in an indefatigable process of reconstruction. An enormous wave of volunteers threw themselves into regenerating stricken cities and shattered infrastructure. A bastion of the revolution, physical culture was no exception: interwar venues were repaired and hundreds of new ones were built. These included flagship stadiums, as well as more modest undertakings: athletics grounds on Croatian islands, mountaineering hunts in Kosovo, and Bosnian bowling alleys among them. Major projects received public funding, but others relied on self-initiative, causing friction between the authorities and zealous locals. As the 'stadium revolution' evolved, professional companies worked on vast football grounds. At its zenith, expensive undertakings like Split's Poljud [built for the 1979 Mediterranean Games] were highly prestigious for the communist authorities. These venues constitute a mixed socialist legacy, but many continue to serve the needs of successor states. Using archival documents and photographs, this essay explores a stadium revolution that unfolded in parallel with the revolution at large. It examines the dynamics that shaped Yugoslav sport and society. Yugoslavia's experience, while unique, did not occur in a vacuum; the case provides a new perspective on the development of sporting infrastructure in revolutionary environments in general.
\end{abstract}

\section{Keywords}

Stadiums; Socialist Yugoslavia; Physical culture; Sporting infrastructure; Football grounds

In the spring of 1978, President Josip Broz Tito visited the construction site of the Poljud sports complex in Split. Rising beside the shores of the Dalmatian coast, it was a vast project with a state-of-the-art stadium and swimming arena at its heart. As the aging revolutionary sat in the middle of the site, surveying a scale model that depicted a bright future, hundreds of builders crowded round to gauge his reaction. The sweeping steel roof structure was only just taking shape, but Tito was reassured that the project, which would be 'one of the most beautiful and cheapest of its kind in Europe', would be completed in time to host the Eighth Mediterranean Games. ${ }^{1}$ Eighteen months later, the leader of socialist Yugoslavia proudly opened the Games before a packed crowd. Yet, within a year, Tito would be dead and the state that he had done so much to establish would begin to unravel. The Mediterranean Games were the biggest sporting event that Yugoslavia had hosted until that point. Its facilities were the pinnacle of a long and fruitful relationship between the communist authorities and sporting infrastructure projects [Figure 1].

Figure 1 here 
In the years after the liberation of the territories that became socialist Yugoslavia, the new state's citizens engaged in an indefatigable process of rebuilding shattered infrastructure and cities reduced to rubble by four years of conflict. An enormous wave of voluntary - and not so voluntary - workers threw themselves into diverse regeneration projects. Yugoslavia's sporting infrastructure, which had been neither extensive nor evenly distributed during the interwar period, was no exception. Voluntary brigades, soldiers and physical culturists set to work, as the incipient state embraced a new physical culture and dedicated scarce resources to laying its rudimentary foundations. In what we might call the 'stadium revolution', thousands of projects sprung up across the state, as government bodies attempted to guide what was rarely a smooth process. Alongside prestigious facilities of national importance, enthusiastic - and occasionally overambitious - clubs in the villages, towns and cities of every constituent republic strove to satisfy their own sporting needs. The authorities continued to make heavy investments in sporting infrastructure over the four and a half decades of socialist Yugoslavia's existence. If physical culture was to serve the revolution, it needed to have suitable stages on which to do so.

The Yugoslav experience did not occur in a vacuum. The potential for sporting infrastructure to contribute to revolutionary movements and state building projects, in both symbolic and practical ways, has been studied in a number of diverse cases. The revolutionary fervour of 1920s Moscow encouraged architects to explore utopian visions for a physical culture stadium fit for the new society, only for less experimental designs - owing much to the advances of western architecture - to win out in the Stalinist years. ${ }^{2}$ In fascist Italy, the regime reaped the rewards of its campaign to construct sporting facilities across the state, keenly aware that 'each sporting work, from the most modest to the monumental, is always a potent and efficient method of propaganda.' ${ }^{3}$ Existing research on Yugoslavia's interwar sports facilities demonstrates that the ancien régime was well aware of the prestige associated with flagship stadium projects, but socialist-era sporting infrastructure remains largely unstudied. ${ }^{4}$ The case of Tito's Yugoslavia shares many similarities with experiences elsewhere, as well as a number of domestic continuities. This essay uses archival material, plans, photographs and newspaper coverage to explore the evolving revolution in stadium construction that unfolded in parallel to the revolution at large. In the process, it examines the dynamics that shaped Yugoslav sport and society, while providing a new perspective on the development of sporting infrastructure in revolutionary environments in general. 


\section{The First Revolutionary Wave}

As Tito's partisans liberated vast swathes of territory in the final years of the war, they were faced with widespread devastation. In Belgrade, the capital of the incipient federal state, nearly half of the buildings lay in ruins, while the city's infrastructure, including $80 \%$ of the tram network, was badly damaged. ${ }^{5}$ Many of the sporting facilities which had existed in the interwar Kingdom of Yugoslavia, albeit of varying quality and by no means evenly dispersed across the state, were damaged or destroyed. Both of Belgrade's best-equipped football grounds fell victim to bombing raids, with the city's rowing club suffering the same fate. It was a similar story in other urban centres, including the Adriatic ports of Rijeka and Split. ${ }^{6}$ As they took a firm grip on power, the Communist Party of Yugoslavia tackled the destruction head on. Sporting infrastructure was high on its list of priorities.

The Party deemed physical culture an indispensible element of the revolution. Yugoslav partisans used it to great effect during the National Liberation Struggle. Rudimentary athletics, football and other games served to maintain and raise fitness levels, while encouraging camaraderie between the diverse nations and nationalities within the partisan movement. After liberation, the new physical culture - heavily inspired by Soviet practice - became a cornerstone of efforts to educate the population and achieve the objectives of the revolution. In May 1945, one of its leading proponents stressed that:

... physical culture can not be detached from the public life of our nation (cultural and educational, political, etc.). Rather, it must be as closely related to it as possible and make its own contribution to the rounded upbringing of our young generation, who will be capable of defending the achievements of our struggle and of rebuilding our charred and ruined country, making it more beautiful than it has even been. ${ }^{7}$

The crucial educational, defensive and regenerating potential of physical culture was also a favourite theme for Tito when addressing youth organisations. ${ }^{8}$ Yugoslav uses of sport and physical education share much in common with those of other twentieth century mass movements, be that in the Soviet Union, fascist Italy, or elsewhere. In each case sport was a means of improving physical and moral health, discipline and patriotism. It offered the potential to increase military capabilities and boost productivity. ${ }^{9}$ More specifically, in communist states 'sport had the quite revolutionary role of being an agent of social change, with the state as pilot.' 10 
Senior figures in Yugoslavia's incipient physical culture organisations were keen to emphasize two crucial differences between socialist physical culture and tainted interwar sport. The latter was condemned as having focused too narrowly upon individual disciplines, often motivated by financial gain. By contrast, its revolutionary successor stressed the detrimental consequences of narrow specialism, which prevented the development of rounded athletes. In the new environment citizens would be encouraged to embrace a diverse range of sporting activities and they would benefit from overarching physical culture societies. ${ }^{11}$ Sloboda [Freedom] Tuzla was a typical example. It eventually encompassed football, athletics, swimming, boxing, waterpolo, basketball, handball, wrestling, chess, tennis, volleyball and bowling. ${ }^{12}$ Interwar sport was also criticised for elitism, in that many clubs were only accessible to a small, often privileged segment of the population. Physical culture on the other hand, would be a mass phenomenon open to everyone, whether in the largest cities or the smallest villages. Via these two defining characteristics - svestranost [multifaceted] and masovnost [mass character] - the new movement would forge the strong workers and soldiers needed to preserve Yugoslavia's hard-won freedom and build a bright socialist future. ${ }^{13}$ Yet, the ambitious undertaking to bring a multifaceted physical culture to the entire population would only be possible with sustained government support, especially in terms of developing the necessary infrastructure.

With the pressing need to rebuild Yugoslavia's shattered economy, but with little in the way of resources to do so, the Party looked to inspire the population to astonishing feats. Drawing inspiration from Soviet Russia's Stakhanovite movement, Yugoslav workers were encouraged to perform shockwork as a means of increasing industrial production. Shockwork and 'comradely' competitions mobilized workers to toil for long hours, at a high tempo, in order to over-fulfil production outputs by large margins. ${ }^{14}$ Another source of highly motivated labour was Yugoslavia's youth. Volunteer labour brigades of young people were assembled to work on large infrastructure projects during the 1940s. Brigades were formed all over the state, with colossal federal groups - numbering in the tens of thousands - assigned to the construction of the youth railway lines of Bosnia and the Brotherhood and Unity Highway between Zagreb and Belgrade. ${ }^{15} \mathrm{~A}$ third source of free labour were the massed ranks of the Yugoslav People's Army. Such 'Voluntary' work was undoubtedly problematic. While thousands of youths willingly devoted themselves to the completion of essential projects, others were forcibly mobilized by zealous local Party leaderships 
desperate to fulfil quotas. Soldiers were also vulnerable to exploitation. Eventually, the negative impact of such practices upon public support resulted in a cooling of enthusiasm for voluntary labour within the Party. ${ }^{16}$ Yet, whether performed willingly or under duress, it undoubtedly served an important role in reconstruction and industrialisation, as well as in the development of sporting facilities.

Often faced with either a complete absence of adequate sports grounds, or facilities which were so badly damaged that they were beyond use, aspiring athletes initially took it upon themselves to rectify the situation. Voluntary endeavours in the field of sport were not particularly new. During the interwar years, clubs relied upon their own labour to secure suitable playing surfaces, or improve facilities. Funds were also obtained on the basis of good will. Hajduk [Brigand] Split built their own clubhouse in the early 1930s, with local businesses donating machinery and materials. ${ }^{17}$ Elsewhere in the town, the workers' football club Borac [Fighter] crafted a ground of its own a few years earlier. Described with hindsight as 'the first shockwork action in bourgeois Yugoslavia', 500 people toiled on the site, completed in $1926 .{ }^{18}$

After the war, the central importance of voluntary work and the self-initiative of physical culturists was emphasized by the federal government's Committee for Physical Culture [Komitet za fiskulturu]. Commenting upon the lack of the 'most basic sporting facilities' in the winter of 1946, the Committee stressed the need for organisations to 'use their own strengths and the initiative of the physical culturists themselves, and not to seek financial assistance from the Peoples' Government until they have explored all of the other possibilities. ${ }^{19}$ Much had already been achieved by this stage.

Within days of the liberation of Split, in the autumn of 1944, shockworkers were repairing Hajduk's stricken pitch. ${ }^{20}$ When the illustrious club subsequently received requests for material assistance from other parts of Dalmatia, it stressed that it was in no position to oblige. Returning from a wartime propaganda tour of liberated Italy, the club 'found only ruins' at its own ground. As a result, it stressed to other aspiring athletes that 'in every branch of public life, including sport, there is a need to work with evermore self-initiative.' ${ }^{21}$ Those who wanted facilities would have to build them. Examples of such self-initiative were widely publicized in the sporting press, with the aim of spurring the population into action. Fiskultura, the newspaper of the Committee for Physical Culture, drew attention to the exploits of the Rudar [Miner] club from 
Kostolac. Consisting of workers and employees of the local coalmine, the club had taken it upon themselves to build a recreational facility:

Above all, with the shockwork of all members, a new, large football pitch was built, enclosed by a fence, with temporary terracing for 300 spectators, a 100 metre running track, a volleyball court, pits for jumping, a high-bar and rings, which as a whole present a very nice vista of a miniature sports stadium. ... At the end of the working day everyone gathered at the sports ground: miners, workers with a digger, from the workshop, office workers, young men and women, as well as pioneers, and in unison they started work with a song. Some levelled the ground, some pushed wheelbarrows of sand, while others dug holes for fence posts, and so on. After 15 days and with the greatest satisfaction, they all saw the fruits of their labour before them: a beautiful and ordered sports ground, the nicest in the whole district. ${ }^{22}$

While championing examples of desirable conduct, Fiskultura also made concrete suggestions for cost-effective building solutions.

Fashioning rudimentary facilities from scratch was not the only means of obtaining locations suitable for the new socialist physical culture. Particularly in larger towns and cities, the remnants of interwar sport could also be harnessed in the new circumstances. When the basketball section of Belgrade's newly formed Crvena zvezda [Red Star] Physical Culture Association was looking for space in which to train and compete, members were faced with a moral dilemma. Within the walls of the colossal Kalemegdan Fortress there were tennis courts and a clubhouse that were tainted by their association with the deep inequalities of interwar sport. Having decided to utilize them nevertheless, the youth of Crvena zvezda transformed the site for their own contemporary purposes:

The tennis courts were turned into a basketball court. The first results were soon revealed: instead of just eight tennis players playing on four courts (and these were those who played more out of snobbery than for the love of sport), the courts at Little Kalemegdan were transformed into a real sporting hive of activity. Hundreds of young men and women, from all of Belgrade's neighbourhoods, train here everyday. ${ }^{23}$

They soon erected a compact multisport arena against the solid walls of the fortress, enabling athletes and spectators to enjoy the stunning greenery of the Kalemegdan Park, while engaging in physical culture.

As the initial flood of revolutionary activity settled into a more measureable stream, the bodies responsible for physical culture at the federal and lower republic level attempted to gain a clearer picture of the state of play. In response to a request for 
information on projects across Yugoslavia, the Committee for Physical Culture received detailed descriptions, breakdowns of costs and plans. From these it is clear that the vast majority of construction was done through voluntary work. Most projects centred upon the laying out of a standard athletics ground, with a football pitch inside the running track and some form of rudimentary terracing for spectators. Many of these facilities, built in the 1940s, are still being used today. Examples in the Bosnian town of Bijeljina and on the Croatian island of Pag are typical of the designs of the era [Figures 2 and 3]. ${ }^{24}$ Thousands of voluntary hours went into these projects. Members of the Serbian Borac Čačak devoted over 20,000 hours to improving their site, even before they had embarked upon the construction of terracing. ${ }^{25}$ In Slovenia, a sports complex for Branik [Defender] Maribor consumed over 100,000 hours, with volunteers shifting 40,000 cubic metres of earth in the process. ${ }^{26}$

Figure 2 here

Figure 3 here

Aside from standard athletics grounds, facilities for a wide range of other sports were also constructed in the immediate postwar years. These included bowling alleys in Hercegovina, swimming pools in Dalmatia, and mountaineering huts in Kosovo. ${ }^{27}$ Given the loud encouragement from the authorities, along with the preference for selfinitiative, it comes as little surprise that some of the early schemes ran into considerable financial and logistical difficulties. Indeed, an over-reliance on local initiative created significant problems for Yugoslavia's physical culture administrators. It is evident that in some cases there were unrealistically high expectations concerning the ability of the state to provide material assistance.

The Vršac Stadium in Serbia's northern province of Vojvodina was one such case. In a letter to the Committee for Physical Culture, the town's stadium construction committee explained that Vršac had lost its 'beautiful and extensive sports ground' during the war. ${ }^{28}$ Discussing the work which had already been done and the money which had been raised locally, the letter admits that the project had run into difficulties, while highlighting that 'it would be a great pity for our youth and for physical culture in general if everything that has been done up until now, with great difficulty and selfsacrifice, fell through.' Nevertheless, it is possible to get a sense of the over-zealous nature of the scheme from the description of the plans: 'from the sketch it can be seen that this stadium should be one of the biggest, not just in Vojvodina, but in the whole 
country'. ${ }^{29}$ It is unclear why the local committee felt the need to furnish a relatively small town with such an arena.

By 1947, it was evident that, while the harnessing of local initiative for construction purposes remained imperative, ambitious self-initiative was proving detrimental:

Material capabilities are often surpassed, the facility is built incorrectly or building is started and enters into difficulties which could have been foreseen and prevented ..., or which have a significant effect upon the construction so that work has to be suspended after a huge number of working hours have been expended, adversely impacting upon the working masses who laboured voluntarily. In the majority of cases, a lack of expertise or ignorance of basic things can be observed. The construction of terraces is usually aspired to, while the pitch itself is of secondary importance. ${ }^{30}$

Almost certainly unaware of the fact, those responsible for physical culture in Yugoslavia were dealing with issues and repeating mistakes that had been made elsewhere in the past. When fascist Italy called upon every commune in the state to provide sporting facilities, in an attempt to upgrade the desperately poor infrastructure which it had inherited, the authorities also stressed the need for local initiative. ${ }^{31}$ As a result, they had to contend with overambitious locales, shoddy workmanship and frivolous expenditure. Stressing that large stadiums were not always necessary, the political elite highlighted the need to focus on the specifications and quality of the playing surfaces themselves. Regulations were drawn up 'to prevent useless fantasies and superfluous costs and serve, at the same time, to avoid the disadvantages of bad economic designs. ${ }^{32}$ At every stage, fascist prefects were encouraged to learn from past mistakes, particularly with regard to financial difficulties. ${ }^{33}$ In this way, the Italian state strove to avoid ill-thought-out projects like Yugoslavia's Vršac Stadium. Yet, although Yugoslav bodies made many of the same mistakes as their erstwhile Italian foes, they would also arrive at the same solutions. In order to combat the less desirable consequences of the revolutionary approach, detailed planning was soon deemed a necessity. Like the sporting administrators of fascist Italy, their Yugoslav counterparts sought functional and cost-effective solutions to the dearth of suitable facilities.

\section{State Intervention: Planning the Stadium Revolution}

When the victorious partisan leadership appointed the modernist architect Nikola Dobrović amid the rubble of liberated Belgrade, they tasked him with envisaging a capital fit for the new socialist Yugoslavia. Elements of the central concept which he 
formulated were published in 1946. The studies of various public spaces in the city, in which he privileged 'grandiose, sweeping perspectives converging on monumental buildings', presented a utopian vision of the future. He had particularly high hopes for the historic Kalemegdan Fortress, the upper part of which perches on a steep cliff overlooking the confluence of the Sava and Danube rivers. While colossal buildings of Balkan-wide importance would be built on the upper fortress - including the national assembly, a pantheon and a museum commemorating the partisan victory - a grand sports stadium which could also host mass rallies was to be built into the cliff on the site of the lower fortifications. ${ }^{34}$ This enormously ambitious and highly symbolic project provides a sense of the importance afforded to physical culture in the immediate postwar years. Yet, the idea was hardly new.

During the second half of the 1930s, a remarkably similar project had reached an advanced planning stage. Following the success of the Berlin Olympics, Yugoslav political leaders impressed by the achievements of Europe's fascist states, became set on the idea of hosting the 1948 Olympic Games in Belgrade. Without sporting facilities suitable for the global spectacle, the state appointed the renowned German architect Werner March - who had been responsible for Berlin's iconic stadium - to design worthy venues. The solution which he arrived at included a large Olympic Stadium in the Lower Town of the Kalemegdan Fortress. The arena would also provide a stunning backdrop for national celebrations. ${ }^{35}$ As the project progressed, it faced stiff opposition locally. The appointment of a foreign architect denied his Yugoslav counterparts the opportunity of competing for the prestigious undertaking, while many justifiably feared the detrimental impact that the construction would have on the unique historical site. Although staggering costs, political crisis and the consequent Axis invasion of Yugoslavia prevented the stadium from being built, it is perhaps unsurprising that the idea was resurrected in the wake of liberation. ${ }^{36}$ Dobrović was himself a leading modernist architect in interwar Belgrade, while in terms of elite sporting infrastructure, the motivations of both the interwar leadership and their communist successors were not so different.

The highly ambitious Kalemegdan proposal also had echoes of the utopian designs for Moscow's International Red Stadium of the 1920s. Neither were ever built. Although the monumental Moscow project was eventually integrated into the Soviet Union's first Five Year Plan, the experimental and ideologically controversial designs never left the drawing board. By contrast, the highly functional Dinamo Stadium, 
completed by the Ministry of Internal Affairs in 1928, provided the Soviet capital with a modern arena, built to the highest international standards. ${ }^{37}$ Socialist Yugoslavia would also travel down this functional path, as postwar planning reined in expensive and overly ambitious visions and operated in the realm of the possible. The flagship stadium which emerged was one of the glowing successes of the state's own inaugural Five Year Plan.

The worst of the wartime damage had been rectified by the time that Yugoslavia unveiled its Five Year Plan in 1947. Modelled explicitly on the Soviet precedent, with the objective of rapid industrialisation, it was an enormous bureaucratic exercise that broke down every element of the highly optimistic forecast into minute detail. The needs of sport were explicitly accounted for, with the Committee for Physical Culture drawing up its own extensive projections for the 1947-51 period. The Plan forecast the construction of 2,000 football pitches with athletics tracks, 3,000 courts for basketball and volleyball, and 500 swimming pools. The state's overarching Five Year Plan allocated 900,000,000 Dinars to the construction of physical culture sites, with over $90 \%$ of these funds reserved for facilities 'of federal and republic-level significance', and a much smaller sum for local-level investments. Alongside state investment, the vast majority of the labour for these projects would continue to come from the voluntary exploits of athletes and other people's organisations. In this hybrid manner, the facilities necessary to bring physical culture to the masses would be realized. ${ }^{38}$

Although Tito's seismic split with Stalin - and the devastating economic impact of the consequent isolation from the emerging eastern bloc - destroyed any hope that the Five Year Plan would be completed, significant parts of its sporting provisions were realized. Moreover, federal and republic level physical culture bodies had been making substantial investments long before the ink was dry on the Plan. They continued to finance dozens of projects across Yugoslavia. In 1947, work was carried out on 86 facilities, with a projected investment of $85,000,000$ Dinars. While large projects absorbed the lion's share of this money, modest facilities benefitting a wide range of sports were also beneficiaries. Nevertheless, more than a quarter of all investment envisaged by the Plan was poured into a single project: the JNA [Yugoslav People's Army, Jugoslovenska narodna armija] Stadium in Belgrade. ${ }^{39}$

The biggest sporting object in the Five Year Plan, the JNA was to serve as both a national stadium and as the home of the army's Partizan Sports Society. As the flagship project of the physical culture movement, it encompassed a number of other 
facilities as part of a multisport complex. The stadium had been in the planning stage for some time, with the Committee seeking an estimate of costs and necessary materials in November 1946, but building work finally commenced in the spring of $1948 .{ }^{40}$ At the head of the project was the architect Mika Janković, who oversaw the construction of a modern arena capable of accommodating 60,000 spectators. Units of soldiers, voluntary youth brigades, and the People's Front provided much of the labour. ${ }^{41}$ Fashioned from reinforced concrete, the stadium shared much in common with earlier rational modernist facilities in Turin, Ankara and elsewhere. It was built in just 18 months, with its 'exposed skeleton' emphasising the functional and cost-effective nature of the design. ${ }^{42}$ In this way, the stadium was in keeping with the broader objectives of planning in Belgrade, which sought only those solutions that were strictly necessary and which made the best use of resources. ${ }^{43}$

Those resources were difficult to come by, with a shortage of building materials hampering the construction of physical culture facilities. This was an issue which impacted upon development across the state, with shortages exacerbated by the extent of wartime devastation, the split with the Soviet Union and the emphasis which the authorities placed on infrastructure and industry. Another major problem encountered by those working on the JNA complex related to the acquisition of the site itself. ${ }^{44}$ With the design competition already completed, the Urban Planning Institute of Serbia [Urbanistički zavod Srbije] intervened to prevent construction of a smaller arena on the envisaged site, while the land which it designated for the main stadium was deemed to be inappropriate by the architects. ${ }^{45}$ Despite the fact that these difficulties delayed its completion, the stadium opened its gates in the winter of 1949, as Belgrade's inhabitants braved the surrounding building site to witness a World Cup qualifier against France [Figure 4]. ${ }^{46}$

\section{Figure 4 here}

Alongside Belgrade's JNA, large stadiums also rose in Yugoslavia's other political centres. In Bosnia and Hercegovina, work on Sarajevo's Koševo Stadium commenced in 1947. Again, it was built largely through voluntary labour, with many citizens giving up their spare time to work on a multipurpose sporting facility that would become the pride of their republic. ${ }^{47}$ From the plans, it is clear that there was no room for superfluous architectural flourishes. The design made effective use of the natural terrain, with the bowl of the stadium dug into the hillside. Every element of its design was functional and cost-effective. Nevertheless, the completed facility would be 
capable of accommodating 30,000 spectators and would contain all of the necessary attributes of a modern stadium capable of hosting international competition. A football pitch, turfed with English grass and framed by track and field facilities, would be illuminated via floodlight pylons. A well-equipped lounge for dignitaries would occupy prime position at the centre of the terracing, while the complex would also include a large public restaurant, parking facilities and other modern necessities [Figure 5]. ${ }^{48}$ The federal Committee for Physical Culture was closely involved, with the engineer Kosta Popović examining plans and proposals, just as he had done for the JNA. ${ }^{49}$

Figure 5 here

Alongside these high-profile cases, tireless work continued at the grass(less) roots of Yugoslav physical culture throughout the period of the first Five Year Plan and beyond. Individuals and societies engaged in modest projects had to deal with very different - but no less challenging - problems to those faced by the state's leading engineers. Indeed, local conditions impacted upon the construction process well into the 1950s. In Dalmatia, the Split Football Sub-Association [Nogometni podsavez Split, NPS] appealed for additional financial support because the clubs under its jurisdiction had to contend with rocky terrain when building new grounds or renovating existing ones. As a result, the process was much more costly than in other parts of the Croatian republic. ${ }^{50}$ In one particular Dalmatian example, land acquisition was a problem which assumed ideological connotations.

SOŠK [Skradinski omladinski športski klub, Skradin Youth Sports Club] was a typical small town physical culture organisation, located on the shores of the Adriatic. When, in 1953, its members sought to improve their football ground, they encountered formidable obstacles. A sense of the club's humble nature is provided by the fact that, until this stage, its ground had served simultaneously as both a football pitch and a cattle market. Before they could engage in the process of widening and lengthening the pitch, Skradin's athletes needed to obtain permission from the owners of the new land. Agreements over parcels in private ownership, or in the possession of the state, were reached without too much difficulty. By contrast:

... the most difficult question was that of the piece of land for widening the pitch, as the plot was owned by the church. It is not necessary here to outline how many times this question was placed on the agenda of our board meetings, how many appeals we made .... Board members even went personally to the see the bishop in Šibenik .... A couple of times the plot was surveyed, land in various places was measured to be ceded in exchange for the church land, but it looks as though a replacement 
could not be found. In other words, the bishop does not like it that the socialist youth is being raised in the spirit of socialism: that it would be better to raise them in the manner that he imagines. ... Seeing that there would never be an end to this, using their own self initiative, the youth took the matter into their own hands [and] ... with the help of members

of the JNA, they started to level the pitch, widen it and lengthen it. ${ }^{51}$

After 2,500 hours of voluntary labour, and with some financial assistance from the NPS, the renovated pitch was ready for football. ${ }^{52}$

Overcoming all manner of difficulties, by the beginning of the $1950 \mathrm{~s}$ Yugoslavia's physical culture movement possessed a large inventory of facilities. Admittedly, many of these were of a rudimentary nature, while even the larger projects resulted in the construction of functional stadiums, rather than architectural masterpieces. Nevertheless, the progress made in the five postwar years was remarkable. Indeed, when taking into account the enormous obstacles which hampered Yugoslavia's development at this time, the achievement was truly astonishing.

\section{Keeping Costs Down: The 1950s and 1960s}

The stadium revolution continued apace for the next two decades, as rapid urbanization and vast construction projects swelled the size of Yugoslavia's major cities. In this environment, the popularity of football in particular - as a game to be played, but also watched - forced physical culture organisations and urban planners to consider ways to increase existing capacity. There simply were not enough pitches in Yugoslav cities, while many of the existing stadiums were no longer capable of accommodating the tens of thousands who wanted to watch the title challenges and cup runs of the most popular football clubs in the country. Partizan Belgrade had the luxury of the JNA, but city rivals Crvena zvezda, as well as Croatian giants Hajduk Split and Dinamo Zagreb, were desperately in need of larger arenas by the beginning of the 1950s. Yet, there were considerable constraints. At a time when the increasingly westward looking Yugoslav state experimented with the introduction of market mechanisms into the economy, investment for sporting infrastructure remained difficult to come by. Only so much could be achieved with unskilled voluntary labour, while suitable land was in high demand for industry and residential requirements. These were the parameters which shaped stadium development for the next two decades.

Drawing upon literature from western Europe, experts published books on the construction of sporting facilities and their maintenance during this period, providing 
diagrams, measurements and details about the required materials. These publications repeated the old mantras regarding the supremacy of functionality and quality over aesthetic considerations, while stressing that careful maintenance was an important means of reducing costs. ${ }^{53}$ Hence, as the stadium revolution began to evolve, some of the guiding principles remained the same.

The city of Split quadrupled in size during the socialist era, rising to over 200,000 inhabitants by $1991 .{ }^{54}$ By the end of the 1940s, Hajduk's patched up Stari plac ground was an interwar relic that was ill-suited to host the eagerly anticipated matches of a club vying for Yugoslavia's highest honours. With a capacity of 6-8,000, the ground occupied a tight plot near the centre of historic Split. Of even more concern, it was one of the only serviceable grounds capable of hosting league football in the growing city. Located on a rocky peninsula, Split's expansion needed to be carefully planned. The Urban Planning Institute [Urbanistički zavod] was well aware of the shortage of sporting facilities, but this was just one of numerous pressing issues that needed to be overcome in the face of rapid urban expansion. The city promised to build a new sports centre and central stadium, with the Croatian Committee for Physical Culture [Komitet za fiskulturu N.R. Hrvatske] voicing its intent to finance the project, and construction envisaged to take several years. In the meantime, tiny Stari plac would have to suffice. ${ }^{55}$

With meagre resources and a confined site limiting potential for major works, Hajduk turned to the tried and tested methods of the revolution: mass voluntary labour would provide the means of improving the ground, with moral and financial support coming from local government, Split's trade union council and regional companies. Under the guidance of prominent local architect and sportsman Fabjan Kaliterna, hundreds of volunteers - including members of the first team - transformed the site [Figure 6]. The pitch was moved so as to provide additional space for terracing, with the stands constructed on three sides giving Stari plac a horseshoe configuration. Among various other improvements, the gates were also relocated to ease spectator access. While the works were ongoing, Hajduk played the entire first half of the 1950 season as the guest of its opponents. ${ }^{56}$

\section{Figure 6 here}

Although always viewed as a temporary solution, the scale of the work threatened to delay Hajduk's return for the second half of the season. Moreover, the project did not receive the unconditional backing of all interested parties: 
While the Hajduk board and players, along with our members of the People's Front [frontovci], tirelessly endeavour to finish the initiated work as soon as possible, on the other side thousands of "friends" of football come to the pitch, observe what is being done-merely criticising while they do so - interfering with the work, and it is not unusual for them to spoil completed works. If these "friends" of football were selfcritical in any way, they would come to the conclusion that their actions were damaging to the work on the ground. If those hundreds of observers made their own contribution, and if they set eyes on our male and female members of the People's Front - among whom there are old ladies over 70 years of age - then the works on the ground would go at a much faster pace ... ${ }^{57}$

This fierce criticism was accompanied by an appeal for more volunteers to ensure that the ground would be completed on time. Sure enough, Split's inhabitants were able to watch Hajduk win its first socialist-era championship at the remodelled Stari plac in the second half of the season.

Yet, although those associated with Hajduk were fond of the ground and its rich tradition, much of the renovation had been of a poor standard. This gave some credence to the mutterings of the aforementioned cynical onlookers. Just three years after the reconstruction works, Stari plac was in such bad shape that it fell foul of a routine hygiene inspection. Conditions in the clubhouse were poor, the toilets for spectators were in a dilapidated and unusable state (there was no provision whatsoever for female spectators), and the terraces were deemed unsafe. These were all problems that had to be rectified prior to the start of the new football season. ${ }^{58}$

The inspection also condemned the state of the pitch. Repeated attempts to grow grass on the surface had failed, despite warnings from the Yugoslav Football Association [Fudbalski savez Jugoslavije, FSJ] that all First League grounds needed to have grass playing surfaces. ${ }^{59}$ The problem was exacerbated by the continued overuse of the facility in the absence of viable alternatives. All of the city's leading clubs, as well as youth teams, were using the ground, and in 1953 they came together to lobby the local government for new pitches and the promised municipal stadium. ${ }^{60}$ No progress was made on a new arena in the short term, but the situation was at least eased slightly when RSK [Radničko sportsko društvo, Workers' Sport Society] Split finally opened a new ground of its own. When the NPS discussed the dearth of senior facilities with the city council [narodni odbor], they also stressed the need to build several pitches to enable the playing of secondary school, company and youth championships. In response, they were reassured that the city planned to build three pitches, as well as 
a modern stadium in the near future. As it transpired, that future was still 25 years away. $^{61}$

Elsewhere, clubs faced many of the same obstacles as their Dalmatian compatriots. Between 1956 and 1964 the population of the Yugoslav capital rose dramatically, with an annual increase of 24,000 inhabitants. ${ }^{62}$ Apart from the JNA, the capital's stadiums were incapable of quenching the thirst of the growing football public. As a result, two more large arenas emerged a decade after work had been completed on Partizan's home. More advanced construction methods and the increasing scale of facilities meant that there was less room for unskilled voluntary labour. Instead, as was the case in other branches of construction, the grand projects of the 1950s and 1960s relied upon professional building companies.

Both of Belgrade's new stadiums strove to create the biggest and best possible facilities with the minimum possible expenditure. Functionality and cost-effective solutions were indispensible. In both cases an innovative solution made the most of an old technique: like Sarajevo's Koševo, the new grounds were fashioned by excavating and exploiting existing terrain. Building terracing directly onto sloping ground was recognized as 'a very economical and practical' method, which also enabled projects to be completed in stages. ${ }^{63}$ The Youth Stadium of Yugoslavia [Omladinski stadion Jugoslavije], overlooking the Danube at Karaburma, opened its gates in 1957, becoming home to OFK [Omladinski fudbalski klub] Belgrade's footballers and other athletes. Once complete, its sweeping bowl was capable of hosting nearly 30,000 spectators. ${ }^{64}$ Two years later, work began on the vast Crvena zvezda Stadium which, like the JNA, was built on the site of an interwar ground. Although the completion of the project was delayed by a lack of finance, the partially built arena opened to the public in 1963, when Crvena zvezda attracted a crowd of 55,000. Becoming the largest stadium in Yugoslavia, the appropriately nicknamed 'Marakana' (after the enormous bowl of Rio de Janeiro's famous arena) accommodated over 100,000 spectators on several occasions in the coming years. ${ }^{65}$

Though unfolding in the same era, the project embarked upon in Zagreb - the capital of the Croatian republic - offered a very different model for stadium development and utilized very different techniques. Founded in 1945, the Dinamo Sports Society inherited what remained of the interwar Maksimir football ground. The site was signed over to Dinamo by the city in 1952 and a year later the city council approved a proposal to build a 65,000 capacity stadium there. This marked the 
beginning of an ambitious piecemeal redevelopment plan, with the project emerging in stages between 1953 and 1975. The concept enabled the municipality to spread the significant cost over a number of years. As in Belgrade, each stage of the design was built by a professional construction company. The initial phase saw the erection of a 9,000 capacity west stand, with a larger north stand following shortly afterwards. In 1961, a towering concrete east stand was built. Then, between 1964 and 1969, the fourth side of the stadium was developed. Adding another 14,500 to the ground's capacity, the south stand also housed a large electronic scoreboard, hotel and other sporting facilities. Subsequent developments included the erection of cutting-edge Philips floodlights and modern parking facilities. In this manner, the city of Zagreb and Dinamo financed the construction of an impressive multisport facility that was capable of hosting international-level competition. Indeed, the Maksimir development offered a taste of what was to come in the latter half of the 1970s. ${ }^{66}$

\section{Zenith: The 1970s and 1980s}

The final phase of socialist Yugoslavia's stadium revolution was characterized by the construction of all-encompassing sports complexes. These meticulously designed facilities, including those built in Sarajevo, Pristina, Split and Novi Sad, housed impressive indoor arenas, swimming pools and ice rinks. They also symbolized the extent to which Yugoslavia's unique socialist experiment had embraced consumer culture, with thousands of square metres of floor space dedicated to retail and hospitality. Indeed, these confident products of late socialism were envisaged as constituent parts of their respective city centres, providing for the diverse needs of citizens. Though constructed to enable the hosting of international championships and exhibitions, the facilities were also designed with the future needs of local sport firmly in mind.

The Bosnian architect Živorad Janković, in collaboration with others, worked on all four of the aforementioned iconic projects. Continuity is clear in the stunning concrete, steel and glass designs. Sarajevo's awarding-winning Skenderija was completed in 1969, with the other three coming a decade later: Pristina's Boro-Ramiz in 1977, Split's Gripe in 1979 (among the facilities for the Mediterranean Games), and Novi Sad's SPENS in $1981 .{ }^{67}$ With the further political decentralization embodied in Yugoslavia's 1974 constitution, it is no surprise that two of these projects were built in the newly empowered autonomous regions of Serbia: Kosovo and Vojvodina. The latter 
example is highly illustrative of a period in which the communist authorities poured vast sums into durable sporting facilities.

The SPENS project, located in Novi Sad, the capital of the Socialist Autonomous Province of Vojvodina, was designed by Živorad Janković, Branko Bulić and other architects from the Sarajevo Institute for Urbanism and Architecture [Institut za urbanizam i arhitekturu]. Built in stages, with the main hall completed in time to host the 1981 World Table Tennis Championship, the SPENS complex had much to offer. ${ }^{68}$ The main hall became the largest indoor space in the country and was capable of accommodating 8,000 spectators for sporting spectacles, cultural events and sociopolitical gatherings. In addition, the complex's enormous roof covered an ice rink, swimming pool, and a series of smaller sports halls. Its long corridors were lined with retail outlets, restaurants and cafes. Outside, the adjacent Gradski [City] Stadium was also redeveloped as part of the project [Figure 7]. In combination, those responsible for the construction of the complex predicted that at least 10,000 of the city's inhabitants would pass through it on a daily basis. Indeed, it was billed as a facility "with which Novi Sad can enter the twenty-first century'. ${ }^{69}$

Figure 7 here

The magnitude of the project demanded vast sums of investment and, like its contemporaries elsewhere in Yugoslavia, SPENS was viewed as an important political statement. During the construction period, Novi Sad was described as one of Yugoslavia's only republic and provincial capitals without 'a magnificent sports hall, let alone a sports centre' ${ }^{70}$ For the prestige of Vojvodina, it was no longer acceptable for the province's athletes to compete in the multi-purpose halls of the Novi Sad Fair. Čedomir Keco, a prominent figure in Novi Sad physical culture, explained to journalists why the city found itself in that situation, while also stressing the significance of the new complex:

In the last ten years, Novi Sad committed itself to the politics of building facilities in community centres and schools. Today, there is not a single Novi Sad school without a hall, or some sports pitch. But, such politics had the effect that Novi Sad does not have a single showpiece [reprezentativni] sports facility. The hall at the showground belongs more to the fair than to us, which does not bother us, but don't athletes also need an appropriate roof over their heads? The idea of building the City Sports Centre is related to the development of the commune and its socio-economic development and achievements. ${ }^{71}$ 
Such advances did not come cheap. Sixty percent of an estimated 1,100,000,000 Dinars was provided by the city itself. The rest of the money was raised in various ways. When the city held a referendum on the proposed facility, its citizens voted in favour of making a voluntary tax contribution towards its construction. Other sources of funds included local workers' organisations and Vojvodina's provincial government, with the Yugoslav lottery also expected to contribute a significant sum. In addition to the immediate costs, those responsible for SPENS had to consider the long-term requirements of the giant site, so as to ensure that it served as a stimulus for physical culture, rather than 'eating Dinars' allocated to sporting activities. ${ }^{72}$

The highly complex and hugely expensive completion of such world-class venues symbolized the dawning of a new era for the stadium revolution. Though by no means statewide, the final phase saw patched-up interwar facilities and makeshift grounds that had been built through the sweat of volunteers replaced with cutting-edge venues. After a thirty year wait for a suitable home, multiple state champion and cup winner Hajduk Split played its final match at the creaking Stari plac in 1979. The club then relocated to the grandeur of the 35,000 capacity Poljud Stadium at the conclusion of the Mediterranean Games. Large sections of Stari plac were demolished immediately, but even at this stage very little was wasted. The floodlights were rebuilt at the stadium of city neighbours RSK, while the ground itself, shorn of most of its terracing, continues to be utilized by Split's rugby club. ${ }^{73}$

Elsewhere, existing venues were renovated to serve the needs of Yugoslav sport. When Sarajevo hosted the Winter Olympic Games in 1984, a range of winter sports facilities and the Zetra Olympic Hall were constructed. The city also benefitted from improvements to its transport infrastructure, new housing developments and hotel accommodation. ${ }^{74}$ Nevertheless, the refurbished Koševo Stadium hosted the opening ceremony, while Skenderija was heavily utilized throughout the Games. ${ }^{75}$ Even during these twilight years for socialist Yugoslavia, volunteers from the Youth Voluntary Labour Association [Savez omladinska radna akcija, SORA] joined professional building firms on Olympic construction sites. ${ }^{76}$

\section{Conclusion}

When socialist Yugoslavia disintegrated in the early 1990s, the successor states were left with a mixed legacy in terms of sporting infrastructure. Facilities like the Poljud continue to serve a crucial function long into the twenty-first century. Its magnificent 
roof and extensive facilities are still an impressive site. Other venues, while showing signs of age, have also been valuable assets for sport in the post-socialist era [Table 1]. Many of these facilities have provided an excellent platform for the region's athletes to develop their talents and compete internationally. In this respect, the designers of Novi Sad's SPENS succeeded in their efforts to leave an enduring legacy in the city. The complex is home to many sports clubs and continues to host international competitions, recently serving as a venue for the European Men's Handball Championship in 2012 and the World Women's Handball Championship a year later. ${ }^{77}$ At the local level, the desire for the venue to become a sporting, cultural and retail hub has also been met to some extent. As a student at the adjacent university between 2008 and 2009, I attended ice hockey, waterpolo and basketball matches there, as well as going to its rock concerts, cinema, cafes, restaurants and shops.

Other venues, which were once the pride of their respective communities, have not aged so well. Belgrade's Omladinski Stadium, built rapidly to serve the immediate needs of the 1950s, is now crumbling. Indeed, the rate of decay is so severe that its main tenants - OFK Belgrade - have been forced to play important matches away from the ground since 2015. Elsewhere, in Sarajevo, the roof of Skenderija's ice rink collapsed under heavy snowfall in 2012 [Figure 8]. ${ }^{78}$

Yet, while new stadiums and arenas have been built across the economically fragile region since the early 1990s, the flagship projects of the socialist era - many of which are in desperate need of investment - still serve as important arenas for elite sport: the JNA, Poljud, Koševo, Marakana, Maksimir, SPENS and others, as well as hundreds of more modest facilities, constitute a rich legacy for socialist Yugoslavia's stadium revolution. An evolving process embodying the frictions of wider society, Yugoslavia's initiative to build the sporting infrastructure that would underpin a mass physical culture was shaped by the state's unique path to socialism. Nevertheless, the process and results have striking parallels to other cases of revolutionary stadium infrastructure drives elsewhere in Europe. Also beset by the magnitude of the task and severe financial limitations, Yugoslavs adopted comparable cost-effective techniques and planning approaches. The results were innovative and enduring.

Figure 8 here

Table 1 here

\section{Acknowledgments}


Many thanks to Robert Kučić, Karlo Grenc and Jurica Gizdić in Split, Tarik Trbić at FK Sarajevo, and the staff of Arhiv Jugoslavije and Državni arhiv u Splitu.

Richard Mills is Lecturer in Modern European History at the University of East Anglia. He has published widely on the interaction between football, politics and nationalism in the former Yugoslavia.

\section{References}

${ }^{1}$ V. Oštrić and F. Pintarić (eds), 'Josip Broz Tito i Sport, 1973-1979', Povijest sporta, 11, no. 43 (1980), 106-31, 118-9; Krešimir Špeletić, Tito i Sport (Zagreb: Stvarnost, 1979), 52-3.

${ }^{2}$ Alexandra Köhring, 'Exploring the Power of the Curve: Projects for an International Red Stadium in 1920s Moscow', in N. Katzer, S. Budy, A. Köhring, and M. Zeller (eds), Euphoria and Exhaustion: Modern Sport in Soviet Culture and Society (Frankfurt: Campus Verlag, 2010), 41-60.

${ }^{3}$ Simon Martin, Football and Fascism: The national game under Mussolini (Oxford: Berg, 2004), 85. Elsewhere, the constitution of Atatürk's modernising Turkey obliged municipalities to provide stadiums and facilities for their inhabitants. Burcu Dogramaci, 'Heading into Modernity: Sporting Culture, Architecture and Photography in the Early Turkish Republic', in Katzer, Budy, Köhring, and Zeller, Euphoria and Exhaustion, 111-23, 116.

${ }^{4}$ Dejan N. Zec, 'Money, Politics, and Sports: Stadium Architecture in Interwar Serbia', in J. Bogdanović, L. Filipovitch Robinson, and I. Marjanović (eds), On the Very Edge: Modernism and Modernity in the Arts and Architecture of Interwar Serbia (1918-1941) (Leuven: Leuven University Press, 2014), 26987; Dejan Zec, 'Proposed Olympic Complex in Belgrade - Project by Hitler's Architect Werner March', International Conference Architecture and Ideology CD Proceedings (2012), 958-66; Petar Đurđev, 'Izgradnja i otvaranje sportskog igrališta "Karađorđe" u Novom Sadu', Godišnjak Istorijskog arhiva grada Novog Sada, 5 (2011), 277-87; Petar Đurđev, 'Rekonstrukcija stadiona "Karađorđe” u Novom Sadu', Godišnjak Istorijskog arhiva grada Novog Sada, 8 (2014), 237-51. Other works straddle political eras to explore the life of iconic sports grounds: Jurica Gizdić and Robert Kučić, Stari Plac: Od ledine do legende (Split: Hrvatski nogometni klub Hajduk, 2009); Dragan Ogurlić (ed.), 100 godina Stadiona Kantrida (Rijeka: Adamić, 2013); Richard Mills, "The pitch itself was no man's land": Siege, Željezničar Sarajevo Football Club and the Grbavica Stadium', Nationalities Papers, 44, no. 6 (2016), Forthcoming.

${ }^{5}$ Brigitte Le Normand, Designing Tito's Capital: Urban Planning, Modernism, and Socialism in Belgrade (Pittsburgh: University of Pittsburgh Press, 2014), xi.

${ }^{6}$ Dejan Zec, 'Oaza normalnosti ili tužna slika stvarnosti? Fudbal u okupiranoj Srbiji (1941-1944)', Godišnjak za društvenu istoriju, 3 (2011), 49-70, 55-6; Zec, 'Money, Politics, and Sports', 277; Kosta Popović, 'Od ledina i "trkališta" do stadiona za 100.000 gledalaca', in Petar Đorđević (ed.), 50 godina BFS (Belgrade: Beogradski fudbalski savez, 1973), 181-6; Đorđe Paljić, 'Iz starih sportskih objekata danas se stvaraju centri za masovni fiskulturni rad', Fiskultura, Belgrade, 26 April 1946; Ogurlić, 100 godina Stadiona Kantrida, 61; Gizdić and Kučić, Stari Plac, 50.

${ }^{7}$ Miroslav Kreačić, 'Razviti masovan fiskulturan rad!', Fiskultura, Belgrade, 20 May 1945.

8 'Maršal Tito o sadašnjim zadacima naše omladine', Fiskultura, Belgrade, 1 November 1945; 'Prvi zadatak naše omladine...', Naš sport, Belgrade, 8 October 1946.

${ }^{9}$ Patrizia Dogliani, 'Sport and Fascism', Journal of Modern Italian Studies, 5, no. 3 (2000), 326-48; James Riordan, 'The Impact of Communism on Sport', Historical Social Research, 32, no. 1 (2007), $110-5$.

${ }^{10}$ Riordan, 'The Impact of Communism on Sport', 110-1.

11 'Fiskultura i sport federalne Srbije', Fiskultura, Belgrade, 5 May 1945.

${ }^{12}$ Muhsin Nalić (ed.) RSD Sloboda Tuzla, 1919-1989 (Tuzla: RSD "Sloboda” and Igtro "Univerzal”, 1989).

13 'Fiskultura i sport federalne Srbije'.

${ }^{14}$ Carol S. Lilly, Power and Persuasion: Ideology and Rhetoric in Communist Yugoslavia, 1944-1953 (Boulder: Westview, 2001), 116-20; Cathie Carmichael, A Concise History of Bosnia (Cambridge: Cambridge University Press, 2015), 110-1.

${ }^{15}$ Lilly, Power and Persuasion, 120-4. 
16 Ibid.

${ }^{17}$ Gizdić and Kučić, Stari Plac, 33-4.

${ }^{18}$ Andrija Križević-Drina, Sportaši Splita u revoluciji (Split: Logos, 1982), 85; Duško Marović and Mihovil Radja, Povijest športa u Splitu, Knjiga druga 1918.-1941. (Split: Splitski savez športova, 2006), 272.

${ }^{19}$ Komitet za fiskulturu Vlade F.N.R.J., 'Zaključci prvog plenarnog sastanka Komiteta za fiskulturu pri Vladi FNRJ', 19 and 20 December 1946, AJ [Arhiv Jugoslavije], f.321, F8, 6.

${ }^{20}$ Gizdić and Kučić, Stari Plac, 51.

${ }^{21}$ Nogometni klub Hajduk, Letter to H.S.K. Hajduk N.O.V.J. from Šime Milutin, Tehnička sekcija Štab V.P.O.S. Dubrovnik, 26 December 1944, HR-DAST-495/69/97 [Državni arhiv u Splitu]; Nogometni klub Hajduk, Letter to Šime Milutin from H.S.K. Hajduk N.O.V.J., 10 January 1945, HR-DAST495/69/107.

${ }^{22}$ AR., 'Primer u koji treba da se ugledamo - Fiskulturnici izgradili sami svoje igralište - Uspešan rad F. D. "Rudara” iz Novog Kostolca', Fiskultura, Belgrade, 5 December 1945.

${ }^{23}$ Paljić, 'Iz starih sportskih objekata'.

${ }^{24}$ Komitet za fiskulturu Vlade F.N.R.J., Letter to the Komitet za fiskulturu Vlade F.N.R.J. from Komisija za fiskulturu Narodne Vlade BiH, 14 January 1948, AJ, f.321, F44; Komitet za fiskulturu Vlade F.N.R.J., 'Skica fiskulturnog igrališta u Pagu', (n.d.), AJ, f.321, F44.

${ }^{25}$ Komitet za fiskulturu Vlade F.N.R.J., Letter to the Komitet za fiskulturu Vlade F.N.R.J. from Fiskulturno društvo "Borac" Čačak, 4 December 1947, AJ, f.321, F44.

${ }^{26}$ K. L. 'U Mariboru otvoren nov sportski stadion', Borba, 13 July 1952.

${ }^{27}$ Komitet za fiskulturu Vlade F.N.R.J., Letter to the Komitet za fiskulturu Vlade F.N.R.J. from Radničko fiskulturno društvo Velež Mostar, 1 July 1947, AJ, f.321, F44; Komitet za fiskulturu Vlade F.N.R.J., Letter to the Komitet za fiskulturu Vlade F.N.R.J. from Fiskulturno društvo Hajduk Split, 27 December 1947, AJ, f.321, F44; Sherafedin Hoxha, 'Sportska društva i klubovi u SAP Kosovu u poslijeratnom razdoblju (1945-1950)', Povijest sporta, 21, no. 85 (1990), 61-9.

${ }^{28}$ Komitet za fiskulturu Vlade F.N.R.J., Letter to the Komitet za fiskulturu Vlade F.N.R.J. from Gradski fiskulturni odbor - Vršac, 6 September 1946, AJ, f.321, F1.

${ }^{29}$ Ibid.

${ }^{30}$ Komitet za fiskulturu Vlade F.N.R.J., 'Zapisnik sa zaključcima II plenarnog sastanka Komiteta za fiskulturu Vlade FNRJ', 20 and 21 August 1947, AJ, f.321, F8, 9-10.

${ }^{31}$ Martin, Football and Fascism, 79-82.

${ }^{32}$ Ibid., 85-6.

${ }^{33}$ Ibid., 81.

${ }^{34}$ Le Normand, Designing Tito's Capital, xi and 30-2.

${ }^{35}$ Zec, 'Proposed Olympic Complex', 960-1.

${ }^{36}$ Ibid., 965-6. Zec, 'Money, Politics, and Sports', 283.

${ }^{37}$ Köhring, 'Exploring the Power of the Curve', 44-57.

${ }^{38}$ Komiteta za fiskulturu Vlade F.N.R.J., 'Zapisnik sa zaključcima II plenarnog sastanka Komiteta za fiskulturu Vlade FNRJ', 20 and 21 August 1947, AJ, f.321, F8, 5.

${ }^{39}$ Komitet za fiskulturu Vlade F.N.R.J., 'Izveštaj o radu komiteta za fiskulturu vlade FNRJ u toku 1947 godine', (n.d.), AJ, f.321, F8, 10-2.

${ }^{40}$ Komitet za fiskulturu Vlade F.N.R.J., Letter from Komitet za fiskulturu Vlade F.N.R.J. to Projektantski zavod Srbije, 24 November 1946, AJ, f.321, F1; Komitet za fiskulturu Vlade F.N.R.J., 'Zaključci prvog plenarnog sastanka Komiteta za fiskulturu pri Vladi FNRJ', 19 and 20 December 1946, AJ, f.321, F8; Ljubomir Vukadinović (ed.), Naš sport u 1948 godini (Belgrade: Naš sport, 1949), 14.

${ }^{41}$ D. Bosiljčić, P. Vuković and D. Šerčić (eds), Partizan sportsko društvo Jugoslovenske armije (Belgrade: SDJA Partizan, 1951), 6-7.

${ }^{42}$ Dogramaci, 'Heading into Modernity', 117; Martin, Football and Fascism, 90.

${ }^{43}$ Le Normand, Designing Tito's Capital, 50.

${ }^{44}$ Komiteta za fiskulturu Vlade F.N.R.J., 'Zapisnik sa zaključcima II plenarnog sastanka Komiteta za fiskulturu Vlade FNRJ', 20 and 21 August 1947, AJ, f.321, F8, 2-3; Le Normand, Designing Tito's Capital, 38-9.

${ }^{45}$ Komiteta za fiskulturu Vlade F.N.R.J., 'Zapisnik sa zaključcima II plenarnog sastanka Komiteta za fiskulturu Vlade FNRJ', 20 and 21 August 1947, AJ, f.321, F8, 2-3 and 9-10.

${ }^{46}$ Bosiljčić, Vuković and Šerčić, Partizan, 6-7.

${ }^{47}$ Dževad Kajan, Sarajevski Derbi: 74 prvenstvene utakmice, 1954-1999 (Sarajevo: Mediapress, 1999), 26-7; Džavid Husić (ed.), Jubilej sportista Bosne i Hercegovine (Sarajevo: Savez sportova Bosne i Hercegovine, 1955), 95. 
${ }^{48}$ Komitet za fiskulturu Vlade F.N.R.J., Letter to Komitet za fiskulturu Vlade F.N.R.J. from Komisija za fiskulturu Narodne Vlade BiH, 12 November 1947, AJ, f.321, F44.

${ }^{49}$ Ibid.; Komitet za fiskulturu Vlade F.N.R.J., Letter from Komitet za fiskulturu Vlade F.N.R.J. to Projektantski zavod Srbije, 24 November 1946, AJ, f.321, F1.

${ }^{50}$ Nogometni podsavez Split, 'Zapisnik vanredna sjednice Upravnog odbora SNP i Komisije za takmičenje SNP', 2 July 1954, HR-DAST-145 [Unsorted material].

${ }^{51}$ Nogometni podsavez Split, 'Referat: Održanoj na II. godišnjoj skupštini NK. "SOŠK” Skradin', 14 December 1952, HR-DAST-145 [Unsorted material].

${ }^{52}$ Ibid.

${ }^{53}$ Slavko Delfin, Športske građevine (Zagreb: Športska stručna biblioteka, 1957), 5; Živojin S. Jovanović, Održavanje objekata za fizičku kulturu (Zagreb: Sportska štampa, 1963), 7.

${ }^{54}$ It is not possible to provide accurate figures for this increase due to changes in the city's boundaries over the period. Nevertheless, Split grew rapidly during the socialist industrialization process.

${ }^{55}$ D. M., 'Preuređenje hajdukov igrališta', Hajdukov vjesnik, Split, March 1950, reproduced in: Gizdić and Kučić, Stari Plac, 61-4.

${ }^{56}$ Ibid.

${ }^{57}$ M. D., 'Igralište, igralište...', Hajdukov vjesnik, Split, May 1950, reproduced in ibid., 65-6.

${ }^{58}$ Nogometni podsavez Split, Letter to N.K. Hajduk Split from NPS President Ljubo Vučetić, 10 November 1953, HR-DAST-145 [Unsorted material]. The dangers of aging facilities built in unregulated ways were also becoming apparent elsewhere. In 1962, a disaster was narrowly avoided in Rijeka, when parts of the overhanging cliffs gave way, with a large crowd beneath. Ogurlić, 100 godina Stadiona Kantrida, 68.

${ }^{59}$ Remarkably, the overused Stari plac did not have a successful grass pitch of its own until the late 1950s. Imported grass having lost the battle with the fierce Dalmatian sun, a solution was finally found by trucking in suitable turf from local meadows. True to the traditions of the ground, the trucks were unloaded by eager volunteers. Gizdić and Kučić, Stari Plac, 77-8.

${ }^{60}$ Nogometni podsavez Split, Letter to N.K. Hajduk Split from NPS President Ljubo Vučetić, 10 November 1953, HR-DAST-145 [Unsorted material]; Nogometni podsavez Split, 'Zapisnik sastanka ... u domu N.K. "Hajduk" u Splitu, a inicijativu navedenog kluba po predmetu korištenja igrališta', 3 November 1953, HR-DAST-145 [Unsorted material].

${ }^{61}$ Nogometni podsavez Split, 'Zapisnik Upravnog odbora SNP', 18 August 1954, HR-DAST-145 [Unsorted material]; Gizdić and Kučić, Stari Plac, 73.

${ }^{62}$ Le Normand, Designing Tito's Capital, 149.

${ }^{63}$ Delfin, Športske građevine, 76.

${ }^{64}$ Mihajlo Todić, 90 godina romantike (Belgrade: OFK Beograd, 2001), 54; OFK Beograd, 'Omladinski stadion na Staroj Karaburmi', http://www.ofkbeograd.co.rs/?tip=menu\&page=53.

${ }^{65}$ Popović, 'Od ledina i "trkališta" do stadiona za 100.000 gledalaca', 181-8; FK Crvena zvezda, 'Dom Crvene zvezde', http://crvenazvezdafk.com/scc/stadion.

${ }^{66}$ Fredi Kramer (ed.), nogometni klub dinamo 1945-1975 (Zagreb: Nogometni klub Dinamo, 1975), 1637.

${ }^{67}$ Pallati i Rinisë Kulturës dne Sportëve, 'Historiku i Pallatit të Rinisë’, http://www.pallatirinise.com/index.php?option=com content\&view=article\&id=1\&Itemid=68; Centar Skenderija Sarajevo, 'Centar Skenderija Sarajevo', http://www.skenderija.ba/index.php/home/centarskenderija-onama.

68 'SPENS' was actually the name for the World Table Tennis Championship [Svetsko prvenstvo $u$ stonom tenisu u Novom Sadu], while the complex was officially called the City Sports Centre "Vojvodina". Nevertheless, the name SPENS has endured among Novi Sad's inhabitants. Earlier projects elsewhere in Yugoslavia had already hosted this international table tennis event. The 1965 edition was held at the new Tivoli Hall in Ljubljana, while Sarajevo's Skenderija played host in 1973.

${ }^{69}$ Jovo Paripović, 'Sportsko imanje na 20 hektara', SN revija, Zagreb, 21 May 1980; Sportski i poslovni centar Vojvodina, 'Sportski i poslovni centar Vojvodina', http://spens.rs/o-nama/.

${ }^{70}$ Paripović, 'Sportsko imanje na 20 hektara'.

${ }^{71}$ Ibid.

${ }^{72}$ Ibid.

${ }^{73}$ Gizdić and Kučić, Stari Plac, 112-5 and 130.

${ }^{74}$ Kenneth Morrison, Sarajevo's Holiday Inn on the Frontline of Politics and War (London: Palgrave, 2016), 50-1.

${ }^{75}$ Centar Skenderija Sarajevo, 'Centar Skenderija Sarajevo', http://www.skenderija.ba/index.php/home/centarskenderija-onama.

${ }^{76}$ Morrison, Sarajevo's Holiday Inn, 54. 
${ }^{77}$ Sportski i poslovni centar Vojvodina, 'Sportski i poslovni centar Vojvodina', http://spens.rs/o-nama/.

${ }^{78}$ Centar Skenderija Sarajevo, 'Centar Skenderija Sarajevo',

http://www.skenderija.ba/index.php/home/dvoranemapa.

\section{Figure Captions}

Figure 1: The innovative roof of the Poljud Stadium, which continues to dominate the skyline of western Split, under construction in 1978. Muzej sporta Split.

Figure 2: Radnik Bijeljina's functional ground is typical of socialist era facilities across the former Yugoslavia. Author, 2014.

Figure 3: Sketch for a proposed physical culture ground in Pag, Croatia, showing a football pitch, as well as track and field facilities (c.1948). Arhiv Jugoslavije.

Figure 4: The JNA is still serving its original purpose long after the demise of the army that built it. Author, 2009.

Figure 5: A 1949 image of the partially built Koševo Stadium. While some terracing is complete, elsewhere the earth is still in the process of being shaped. FK Sarajevo Collection, Sarajevo.

Figure 6: Volunteers carrying out work at Stari plac during the 1950 reconstruction. Zaklada Karlo Grenc, Split.

Figure 7: The main arena at SPENS towers over the adjacent City Stadium. Author, 2009.

Figure 8: The Skenderija Centre in Sarajevo is showing signs of age, but much of the complex is still serving the city. Author, 2013. 